\title{
HEALTH STATUS OF AN ELDERLY POPULATION IN SHARPEVILLE, SOUTH AFRICA
}

\section{Prof. Wilna H Oldewage-Theron}

BSc (Hons), MSc, PhD (Dietetics) PGDip (Hospital Dietetics)

Director: Institute of Sustainable Livelihoods, Vaal University of Technology, Vanderbijpark

Corresponding author: wilnaold@lantic.net

\section{Dr Lilian Salami}

BSc (Hons), MSc (Food and Nutrition), PhD (Nutrition), PGDip (Education)

Postdoctoral fellow: Institute of Sustainable Livelihoods, Vaal University of Technology, Vanderbijpark

\section{Dr Francis B Zotor}

BSc (Hons), MSc (Biotechnology), PhD (Nutrition), PGDip (Higher Education)

Postdoctoral fellow: Institute of Sustainable Livelihoods, Vaal University of Technology, Vanderbijpark

\section{Prof. Christine Venter}

BSc (Hons), MSc, DSc (Dietetics/Nutrition), BSc (Physiology)

Consultant Research Professor: Institute of Sustainable Livelihoods, Vaal University of Technology, Vanderbijpark

Keywords: elderly; health; nutritional status; low income; household food insecurity

\begin{abstract}
The objective of this cross-sectional study was a comprehensive nutrition and health assessment to provide a basis for future intervention strategies for an elderly population attending a day-care centre. Socio-demographic, health and 24-hour recall dietary intake questionnaires were administered and anthropometric and biochemical measurements taken. The results indicate that the majority of respondents had an income of between R501 and R1 000 (South African rand) per month and most of them reported an occasional lack of funds to meet basic household needs, confirming the presence of food insecurity. Daily dietary intakes (mean \pm Standard Deviation [SD]) of the women were $5395 \pm 2946 \mathrm{~kJ}$ energy, $47 \pm 27 \mathrm{~g}$ protein, $28 \pm 21 \mathrm{~g}$ fat and 196 $\pm 123 \mathrm{~g}$ carbohydrates compared to $8641 \pm 3799 \mathrm{~kJ}$, $86 \pm 48 \mathrm{~g}, 49 \pm 32 \mathrm{~g}$ and $301 \pm 139 \mathrm{~g}$ of the men, respectively. The majority (83.6\%) of the women were overweight (body mass index $[B M I] \geq 25$ ) or obese (BMI $\geq 30$ ) whilst $78 \%$ had a mid-upper arm circumference (MUAC) of $\geq 21.7 \mathrm{~cm}$. Mean intakes of micronutrients were low in comparison to reference standards and serum zinc levels were suboptimal. Obesity, hypertension and raised total serum cholesterol levels indicated an increased risk for coronary heart disease. It can be concluded that a low income, household food insecurity and risk factors associated with malnutrition and non-communicable diseases were prevalent in this elderly population.
\end{abstract}

\section{OPSOMMING}

Die doelwit van hierdie dwarssnitstudie was 'n omvattende bepaling van voeding- en gesondheidstatus om as basis te dien vir toekomstige intervensiestrategieë vir 'n groep bejaardes wat' $n$ dagsentrum besoek. Sosiodemografiese, gesondheid- en 24-uur herroep-dieetinname vraelyste is voltooi en antropometriese en biochemiese metings is geneem. Die resultate het bevestig dat die meerderheid respondente ' $n$ maandelikse inkomste van tussen $R 501$ en R1 000 (Suid-Afrikaanse rand) gehad het. Die meeste het 'n geldtekort vir basiese huishoudelike behoeftes gerapporteer wat dui op huishoudelike voedselinsekuriteit. Daaglikse dieetinnames (gemiddeld \pm standaardafwyking [SA]) van die vroue was onderskeidelik $5395 \pm 2946 \mathrm{~kJ}$ energie, $47 \pm 27 \mathrm{~g}$ proteïen, $28 \pm 21 \mathrm{~g}$ vet en $196 \pm 123 \mathrm{~g}$ koolhidrate in vergelyking met $8641 \pm 3799$ kJ, 86 $\pm 48 \mathrm{~g}, 49 \pm 32 \mathrm{~g}$ en $301 \pm 139 \mathrm{~g}$ vir die mans. Die meerderheid (83.6\%) van die vroue was oorgewig (liggaamsmassa-indeks $[L M I] \geq 25)$ of vetsugtig (LMI $\geq 30$ ) en $78 \%$ het ' $n$ middel-bo-armomtrek (MUAC) van $\geq 21.7 \mathrm{~cm}$ gehad. Gemiddelde mikronutriëntinnames was laag in vergelyking 
met die verwysingstandaarde en serumsink was suboptimaal. Vetsug, hipertensie en verhoogde totale serumcholesterolvlakke het op ' $n$ verhoogde risiko van kardiovaskulêre siekte gedui. Die resultate het dus bewys dat lae inkomste, huishoudelike voedselinsekuriteit en die risikofaktore wat met wanvoeding en leefstylsiektes geassosieer word, teenwoordig was.

\section{INTRODUCTION}

During the 1980s, the average life expectancy at birth for South Africans increased steadily. However, the mortality impact of the country's severe Acquired Immune Deficiency Syndrome (AIDS) epidemic is evident in the considerable drop in life expectancy from 61.6 to a projected low of 49.7 in 2006 (Steyn, Bradshaw, Norman, Joubert, Schneider \& Steyn, 2006:9). Nevertheless, it is estimated that 2.9 million people in South Africa (SA) are 60 years and older, constituting $6.2 \%$ of the total population (Charlton, Bourne, Steyn \& Laubscher, 2001:31). The World Health Organization (WHO) defines "elderly" as all persons over the age of 60 . In $1980,8.5 \%$ of the world population was elderly, increasing to $9.4 \%$ in 1990 and $11 \%$ in 2000. By 2020, it is projected that of the total global population of 7.5 billion people, 13.3\% will be elderly (Solomons, 2001:1).

Given the multiplicity of environments, nature of societal changes, globalisation and the genetic and evolutionary experience across regions, generalisation about the health of the growing elderly population is complex (Solomons, 2001:1). It is, however, certain that the increasing number of elderly people in developing countries will be vulnerable to the health problems that are associated with low-income societies, and that their diet and nutritional status will interact with these conditions. Ageing individuals may be intrinsically vulnerable to undernutrition and its associated infectious diseases, as well as to overnutrition and the risks associated with chronic diseases of lifestyle, thus a double burden of disease (Solomons, 2001:2). People who live at subsistence levels often have no choice but to consume monotonous diets that are poor in nutrients. Impoverished people in cities often consume fatty and sugary foods that are more affordable (Cannon, 2001:1). Charlton, Kolbe-Alexander and Nel (2005:1040) recently demonstrated a nutrient-diluting effect of added sugars in elderly black South African women.

Increased urbanisation among the black population in SA has led to significant increases in diseases of lifestyle (Vorster, 2002:243; Van Rooyen, Kruger,
Huisman, Wissing, Margetts, Venter \& Vorster, 2000:779). The prevalence of the malnutrition problem amongst the elderly in SA is not clearly defined owing to the absence of a national nutrition surveillance programme. The only data available consists of single fragmented surveys that have been undertaken amongst isolated groups. There is thus an urgent need in SA for research on the underlying causes of malnutrition and food insecurity in the elderly (Lemke, Jansen van Rensburg, Vorster \& Zichea, 2001:21), as it has been recognised that proper nutrition and physical activity can extend people's lives and that nutrition intervention can assist in the promotion of healthier ageing, both in the prevention and management of chronic diseases and their consequences (Dausch, 2003:683).

In view of these facts and the present situation, it is strongly argued that a baseline survey with a follow-up nutrition intervention is a highly relevant endeavour in the case of the elderly in Sharpeville, with nutrition education included in all the phases of the project. Sharpeville is situated in the Vaal Region, an industrial, polluted area approximately $70 \mathrm{~km}$ south of Johannesburg, with a population of 794599 people, $47.9 \%$ of whom are unemployed and of which $46.1 \%$ of households live in poverty (Mcllrath \& Slabbert, 2003:13,21). The main objective of this study was a comprehensive nutrition and health assessment to provide a basis for the implementation of intervention strategies for the elderly population. The article consequently focuses on the socio-demographic and health profile, including the nutritional status, of the elderly persons attending a newly established (three months old) day-care centre two days a week (Mondays and Wednesdays) in Sharpeville. The day-care centre offers skills training and religious activities aimed at the low-income elderly (aged $\geq 60$ years) as well as breakfast and lunch on the days that the subjects attend the centre. The results of this project will be used when planning appropriate intervention programmes for the elderly in this community, commencing with the elderly attending this care centre as a pilot study and ultimately assisting in the fight against disease and malnutrition, thereby contributing to the national health plan aimed 
at improving the health care system for all South Africans.

\section{METHODS}

\section{Sampling and respondents}

Before this cross-sectional baseline survey was conducted, introductory visits were made to the daycare centre for the elderly in Sharpeville for observation purposes and to introduce the researchers, explain the objectives of the project and obtain consent for the project from the elderly persons attending the centre. The Medical Ethics Committee for research on human beings of the University of the Witwatersrand approved the study (R14/49).

The sample size calculation (The Survey System, n.d.) used for this study was as follows:

$$
Z^{2 *}(p) *(1-p)
$$

Sample size $=$

$$
c^{2}
$$

where:

$Z=Z$ value (e.g. 1.96 for $95 \%$ confidence level) $p=$ percentage picking a choice, expressed as decimal $(p=0.5$ used for sample size needed) $c=$ confidence interval, expressed as decimal (e.g. $0.05=5$ )

A total of 169 respondents were thus needed for this cross-sectional survey to obtain statistically representative data for this community. However, 170 men and women were randomly selected for the survey from an alphabetical list of names provided by the care centre (every second name). Eight fieldworkers, speaking the various indigenous languages of $\mathrm{SA}$, were recruited and trained using a training manual and participatory facilitating methods. The data from 169 questionnaires were completed and analysed.

\section{DATA COLLECTION}

\section{Characteristics of participants}

A socio-demographic and health questionnaire was compiled in English. Reproducibility of the questionnaire was tested by having the same ten elderly persons complete one questionnaire each week for a period of four weeks and comparing the answers. Based on the results the questionnaire was accepted to be reproducible as a high correlation was found ( $r>0.6, p \leq$ 0.05 ) for the variables of marital status, type of house, monthly income, medication and number of household income contributors. All the respondents were interviewed by the fieldworkers to obtain demographic data such as age, gender of the respondents in the household, home language, levels of education, health profiles and socio-economic data. The activity levels were determined by administering an adapted, validated activity questionnaire used by the Florida International University for the programme "Eat Better \& Move More" for the elderly (Wellman, Weddle, Sanchez \& Rosenzweig, 2004:58).

\section{Dietary assessment}

A pre-validated, structured, 24-hour recall questionnaire (Oldewage-Theron, Dicks, Napier \& Rutengwe, 2005:17) was administered twice, a month apart, by the fieldworkers. A limitation of the 24-hour recall is that it does not provide a reliable estimate of an individual's intake owing to day-to-day variation (Margetts \& Nelson, 2000:139). However, owing to the advantages of speed and ease of administration and the relatively short attention span of the elderly respondents, the 24-hour recall method was used. Because breakfast and lunch were served on these days, it was decided to complete the 24-hour recall on two occasions for days when the elderly did not attend the care centre (Sundays and Tuesdays) to obtain quantitative, descriptive information about usual food consumption patterns and dietary intake. Food models were used simultaneously to determine portion sizes. An average intake of the two days was calculated for the various nutrients. The main objective of this study was not to determine the food consumption and dietary intake patterns, and differences between weekdays and weekends were thus not calculated for this elderly group of people.

\section{Anthropometric indices}

Weight, height and mid-upper arm circumference (MUAC) were measured using standard measurements and body mass index (BMI) was calculated as weight 
$(\mathrm{kg})$ divided by height squared $\left(\mathrm{m}^{2}\right)$. Weight was measured on two new Philips electronic bathroom scales model HF350 and height was measured with a Scales 2000 portable stadiometer. A Tanita model BF-522 bioelectrical impedance scale was used to measure body fat percentage. The respondents were fasted and did no exercise 12 hours prior to the measurements to ensure normal hydration, which is a prerequisite for accurate testing. MUAC was measured using a Seca non-stretch tape.

\section{Biochemical indices}

Breakfast was served between 08:00 and 09:00 at the care centre and the elderly indicated that no food was consumed before leaving home for the care centre. One of the requirements for the biochemical analyses was that the respondents had to be fasting and they were advised at the information session held before the project commenced to fast, and were again verbally reminded the day before the biochemical measurements were taken. A poster with all the data collection dates, procedures and requirements was also displayed in the care centre for at least two weeks before the data collection period. However, no proof could be obtained that the subjects did not have anything to drink or eat before the measurements were taken.

A subsample of 60 elderly persons was selected randomly for the biochemical data collection. Blood samples were taken by qualified nursing sisters using a Vacutainer needle from the vena cephalica of seated subjects after an 8-12 hour fast. Blood pressure and body temperature were measured by the same nursing sisters using standardised techniques.

The blood was separated within two hours of blood collection. Two medical technologists continuously audited the separating procedure. Serum for the analyses of ferritin, total protein, albumin, vitamin $B_{12}$ and folate was stored at $-10{ }^{\circ} \mathrm{C}$ until analysis in the laboratories of the Vaal University of Technology. Serum for retinol, vitamin $E$ and zinc analyses was covered with aluminium foil and stored at $-10{ }^{\circ} \mathrm{C}$ until it was transported to the Nutritional Intervention Research Unit of the Medical Research Council (MRC) in Cape Town.

All blood parameters were analysed according to standard protocol. The following analyses were performed: haematocrit (Hct) (numeric integration [Coulter counter ABX MICROS ${ }_{\mathrm{CT}}$ ), haemoglobin $(\mathrm{Hb})$ (cyanmethaemoglobin colorimetric method [Coulter counter $A B X$ MICROS $\left._{C T}\right]$ ), red blood cell count (RBC) (Coulter counter $A B X$ MICROS $_{C T}$ ), serum glucose (colorimetric method [Konelab ${ }^{\mathrm{TM}}$, GOD-POD]); serum albumin (colorimetric [Konelab $\left.{ }^{\mathrm{TM}}, \mathrm{BCG}\right]$ ), and total protein (colorimetric [Konelab ${ }^{\mathrm{TM}}$ ]) serum folate (immunoturbidity [TOSHO, AIA-PACK B12]), vitamin $\mathrm{B}_{12}$ (immunoturbidity [TOSHO, AIA-PACK B12]), retinol (high performance liquid chromatography (HPLC)), iron (colorimetric [Roche Unimate 5 Iron]), ferritin (immunoturbidometric method [Roche Unimate 3 FERR]), zinc (non-diluted serum flame atomic absorption spectrophotometry), total cholesterol and triglycerides (homogenous enzymatic colorimetric [Konelab $\left.{ }^{\mathrm{TM}}\right]$ ).

\section{STATISTICAL ANALYSES}

Data analysis was done using the Statistical Package for Social Sciences (SPSS) for Windows version 10.0 program for all variables except dietary intake data. Dietary intake and food consumption data were analysed by a registered dietician using the Foodfinder $\AA$ version 3 program, developed by the MRC. Daily nutrient intakes are reported as means and standard deviations for the two 24-hour recalls for each subject and for the male and female groups separately. The Levene's t-test for equality of variances was used to evaluate differences between nutrient intake and biochemical variables of men and women. Frequencies were used to determine the percentage of participants with nutrient intakes below the estimated average requirement (EAR) values (Institute of Medicine, 2003:17-88).

In order to assess the validity of the dietary assessment method, reported energy intakes were compared with estimated energy requirements (EER) using the equation suggested by the Institute of Medicine (2003:15) with a physical activity level factor of 1.0 for sedentary men and women.

\section{RESULTS}

\section{Characteristics of the respondents}

The majority of the respondents, aged between 60 and 110 years, were black (100\%), widowed $(70.4 \%)$, 
women $(90.5 \%)$, with a mean age of 71.2 years. Only $24.6 \%$ had attended secondary and tertiary institutions, indicating a low literacy level. A small percentage lived alone $(5 \%)$, whilst the majority of respondents shared the house with other family members. The average household size was 4.9 persons. $99 \%$ of the respondents lived in brick houses with $\leq$ two rooms (29.4\%), three to four rooms (40.5\%) or more than four rooms (30.1\%). The majority of the respondents had resided in Sharpeville permanently for more than five years and had access to clean, safe water, electricity, toilet facilities and waste removal services.

The major health problems experienced by the participants were eye, ear, nose and throat infections, painful joints and chronic headaches. Most of them used chronic medication, of which $29.6 \%$ was for the treatment of hypertension. $68 \%$ suffered from hypertension ( $\geq 160 / 95 \mathrm{~mm} \mathrm{Hg}$ when measured), however, only $36.8 \%$ of the respondents used hypertensive medication. The respondents were not very active as only $14.5 \%$ reported heavy exercise/activity levels and $32.3 \%, 27.4 \%$ and $25.8 \%$ reported moderate, light or no exercise/activity levels, respectively, as measured by the validated physical activity questionnaire. With regard to smoking and drinking, $88.3 \%$ of the respondents never smoked and $88 \%$ did not take alcohol. This result could be influenced by the fact that $90.5 \%$ of the sample consisted of women. However, a relatively large percentage of the sample used snuff. The results also indicate that the majority of respondents visited the local clinic $(63.6 \%)$ on foot $(64.3 \%)$ when ill.

The anthropometric indices of the women are reported here as they were the majority of the sample. The BMI indicated 16.4\% normal weight (BMI 18-24.9), 29.5\% overweight (BMI 25-29.9), 27.9\% obese (BMI 30-34.5) and $26.2 \%$ very obese (BMI $35+$ ). The body fat composition indicated that $50 \%$ of the women had more than $40 \%$ fat. The mean MUAC was $33.4 \pm 0.7 \mathrm{~cm}$, falling between the 75th and 90th percentile of the United States Health and Nutrition Examination Survey (NHANES 1) for the elderly between 65 and 74.5 years old (Mahan \& Escott-Stump, 2000:1189-1190). This is further proof of obesity in this sample.

Table 1: Selected biochemical indices of a sample of the elderly subjects $(n=67)$

\begin{tabular}{|c|c|c|c|c|c|c|c|}
\hline Parameter & $\begin{array}{l}\text { Normal } \\
\text { range }\end{array}$ & 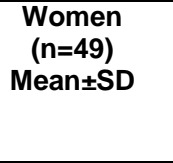 & $\begin{array}{c}\text { Women } \\
(\%) \\
\text { with low } \\
\text { values }\end{array}$ & $\begin{array}{c}\text { Men } \\
(n=18) \\
\text { Mean } \pm S D\end{array}$ & $\begin{array}{c}\text { Men } \\
(\%) \\
\text { with low } \\
\text { values }\end{array}$ & $\begin{array}{c}\text { Total } \\
(n=67) \\
\text { Mean } \pm S D\end{array}$ & $\begin{array}{c}\text { Total } \\
\text { group (\%) } \\
\text { with low*l } \\
\text { high** } \\
\text { values }\end{array}$ \\
\hline Total serum iron\# & $\begin{array}{r}10-30 \\
\mu \mathrm{mol} / \mathrm{l}\end{array}$ & $15.7 \pm 7.9$ & 18.4 & $16.6 \pm 7.4$ & 27.8 & $16.0 \pm 7.8$ & $\begin{array}{r}20.9^{*} / \\
3.0^{* *} \\
\end{array}$ \\
\hline Serum ferritin§ & $\begin{array}{r}18-250 \\
\mathrm{ng} / \mathrm{ml}(\mathrm{m}) \\
12-160 \\
\mathrm{ng} / \mathrm{ml}(\mathrm{w})\end{array}$ & $179.3 \pm 289.8$ & 4.2 & $177.6 \pm 190.9$ & 5.6 & $178.9 \pm 265.1$ & $\begin{array}{r}4.5^{\star} / \\
42.4^{* *}\end{array}$ \\
\hline Haemoglobin\# & $\begin{array}{r}13.5-17.5 \\
\mathrm{~g} / \mathrm{dl}(\mathrm{m}) \\
11.5-15.5 \\
\mathrm{~g} / \mathrm{dl}(\mathrm{w})\end{array}$ & $13.6 \pm 1.6$ & 40.8 & $13.6 \pm 1.9$ & 55.6 & $13.6 \pm 1.6$ & $44.8^{*} / 1.5^{* *}$ \\
\hline Haematocrit\# & $\begin{array}{r}40-52 \% \\
(\mathrm{~m}) \\
36-48 \%(\mathrm{w}) \\
\end{array}$ & $41.7 \pm 4.0$ & 30.6 & $42.0 \pm 5.4$ & 38.9 & $41.8 \pm 4.4$ & $32.8^{*} / 3.0^{* *}$ \\
\hline Serum zinc ${ }^{\wedge}$ & $\begin{array}{r}50-150 \\
\mu \mathrm{g} / \mathrm{dl}\end{array}$ & $65.8 \pm 7.9$ & 69.4 & $62.4 \pm 11.7$ & 83.3 & $64.9 \pm 9.1$ & $73.1^{*} / 0^{* *}$ \\
\hline Serum folateף & $\begin{array}{r}5.9-45.4 \\
\mathrm{nmol} / \mathrm{l}\end{array}$ & $15.0 \pm 6.9$ & 0 & $13.6 \pm 5.4$ & 0 & $14.6 \pm 6.5$ & 0 \\
\hline Serum retinolף & $20-30 \mu \mathrm{g} / \mathrm{dl}$ & $57.3 \pm 17.3$ & 0 & $51.6 \pm 14.1$ & 0 & $55.8 \pm 16.6$ & 0 \\
\hline Vitamin $B_{12} \mathbb{T}$ & $\begin{array}{r}156-672 \\
\mathrm{pmol} / \mathrm{l}\end{array}$ & $333.3 \pm 141.0$ & 2.1 & $332.3 \pm 120.2$ & 5.6 & $333.1 \pm 134.8$ & $3^{*} / 1.5^{\star *}$ \\
\hline
\end{tabular}

No statistically significant difference between men and women were found at p?0.05 (Levene's test for equality of variances)

(\#Hoffbrand et al. 2001:331; §Konelab 20i reagent Kits; ๆ SA Medical Research Council, ^ Yetiser,et al. 2002:329333)

* Low values, ** high values (compared to normal range) 
The biochemical data (Table 1) indicated that the majority of respondents had normal haematological indices. The mean serum triglyceride level was $1.2 \pm 0.6$ $\mathrm{mmol} / \mathrm{l}$, which was within the normal range. Although the mean serum cholesterol level was $5.4 \pm 1.4 \mathrm{mmol} / \mathrm{l}$, indicating borderline risk for cardiovascular disease (CVD), the majority of the elderly had normal cholesterol levels $(<5.2 \mathrm{mmol} / \mathrm{l})$, with $41.8 \%$ lying within the borderline risk of CVD levels (5.2-6.2 mmol/l). A significantly higher percentage of women had serum cholesterol levels above the normal cut-off point when compared to the men, thus indicating greater risk for CVD in the female subjects. The majority of the elderly had normal blood glucose levels. However, $22.4 \%$ had high levels ( $>5.9 \mathrm{mmol} / \mathrm{l}$ ) that could be associated with a risk of diabetes mellitus. The men had statistically significantly higher serum glucose levels $(6.4 \pm 3.6 \mathrm{mmol} /$ I) compared to women $(5.2 \pm 2.1)(p \leq 0.05)$. The distribution of serum mineral levels indicated that the majority of respondents had normal iron and ferritin levels, but $73.1 \%$ of the subjects had low serum zinc levels ( $<50 \mu \mathrm{g} / \mathrm{dL}$ ) (Yetiser, Tosun, Satar, Arslanhan, Akcam \& Ozkaptan, 2002:329-333). However, 42.4\% and 3\% of the respondents had serum ferritin and iron levels higher than the cut-off point, respectively. Only 20.9\% of the respondents had low serum iron levels ( $<9$ and $11.6 \mu \mathrm{mol} / \mathrm{l}$ for women and men, respectively), but $35.8 \%$ and $47 \%$ had low haematocrit and haemoglobin levels, which could be indicative of iron deficiency anaemia. The majority of the elderly had normal serum vitamin $B_{12}$, retinol and folate values. The data were further analysed for correlations between BMI and serum glucose levels, cholesterol and triglycerides, but based on the one-tail Pearson correlation test, no statistically significant correlations were found.

\section{Dietary intake and food consumption pat- terns}

The EAR is defined as "the dietary intake that meets the estimated needs of a nutrient for $50 \%$ of individuals in a gender specified group, at the given life-stage" (Institute of Medicine, 2003) and is used as the basis for the recommended dietary allowance (RDA). The EAR is usually used to estimate the prevalence of inadequate intakes of nutrients within a group (Institute of Medicine, 2003:8, 11) and, although the majority of households surveyed indicated consumption of three $(58.8 \%)$ or two (28.8\%) meals daily, the nutrient analysis of the diets indicated deficient intakes for a number of nutrients when compared to the EAR. These included dietary fibre, calcium, selenium, vitamins $A, B_{6}, D, E$, folate and biotin. The mean of two 24-hour recall analyses also showed deficient intakes by the female participants of total energy as well as magnesium, zinc, thiamin, riboflavin, niacin, vitamins $B_{12}, C$ and pantothenate (Institute of Medicine, 2003:17, 25, 37, $42,49,55,60,62,65,69,71,73,76,79,81,83,85$, 88). Table 3 shows the top 20 most frequently consumed items and the average daily intake of respondents who consumed these foods on the days included in the 24-hour recalls. The majority of food items consumed were carbohydrate-based, and although chicken, beef and eggs appeared as protein sources, these were consumed by a minority of respondents (38, 21 and 24 , respectively). Milk was consumed by 73 respondents but the mean daily intake was small $(67 \mathrm{~g})$. Although fruit and vegetables also appeared on the top 20 food consumption list, the only fruits that were consumed included apples, oranges, bananas and pears. The majority of elderly persons did not consume any fruit or vegetables. The only vegetables consumed were cabbage, coleslaw, spinach, pumpkin, carrots, beetroot and tomato and onion mix. Not only was the frequency of fruit and vegetable intake very low, but the portions were also very small and did not meet the recommended intake of $400 \mathrm{~g}$ per day (Love \& Sayed, 2001:S29). This explains the low fibre intake.

The EER is defined as the "average dietary energy intake that is predicted to maintain energy balance in a healthy adult of a given age, gender, weight, height and level of physical activity, consistent with good health" (Institute of Medicine, 2003:15). In this study the EER for sedentary men (6 $809 \mathrm{~kJ})$ and women (6 $182 \mathrm{~kJ})$ was compared with the mean reported energy intake of men $(8640 \mathrm{~kJ})$ and women $(5394 \mathrm{~kJ})$ to validate the dietary intake data by means of a paired t-test. In the women, there was evidence of underreporting as a statistically significant difference $(p \leq 0.05)$ between EER and reported energy intake was found. $61 \%$ of the women reported energy intakes of below the EER with the reported intake on average 13\% lower than EER. The opposite was found in the men. The reported energy intake of the men was statistically significantly higher compared to the EER $(p \leq 0.05)$, thus indicating overreporting by $58 \%$ with the reported intake on average $26 \%$ higher than EER. No statistically significant 
difference was found between the EER and reported energy intake for the total sample.

The meals supplied by the day-care centre contributed on average $6292 \mathrm{~kJ}, 59 \mathrm{~g}$ protein, $47 \mathrm{~g}$ fat and $212 \mathrm{~g}$ carbohydrates. This is an equivalent of $92 \%$ and $102 \%$ of energy requirements for women and men, respectively, as well as $128 \%$ of protein and $212 \%$ of carbohydrates when compared to the EAR. Furthermore, the meals provided $216 \%$ and $189 \%$ of dietary iron and zinc recommendations, respectively (Institute of Medicine, 2003).

Table 2: Analysis of two 24-hour recalls: mean daily intakes of a sample of the elderly subjects ( $n=101)$

\begin{tabular}{|c|c|c|c|c|c|c|c|}
\hline Nutrient & $\begin{array}{c}\text { Women } \\
(\text { mean } \pm \text { SD }) \\
(n=81)\end{array}$ & $\begin{array}{c}\text { Wom } \\
\text {-en } \\
(\%) \\
<100 \\
\% \text { of } \\
\text { EAR }\end{array}$ & $\begin{array}{c}\text { Men } \\
(\text { mean } \pm \text { SD) } \\
(n=20)\end{array}$ & $\begin{array}{l}\text { Men } \\
(\%) \\
<100 \\
\% \text { of } \\
\text { EAR }\end{array}$ & $\begin{array}{c}\text { Total group } \\
\text { (mean } \pm \text { SD) } \\
(n=101)\end{array}$ & $\begin{array}{l}\text { Total } \\
\text { grou } \\
\mathrm{p}(\%) \\
<100 \\
\% \text { of } \\
\text { EAR }\end{array}$ & EART \\
\hline Energy (kJ) & $5394 \pm 2946 *$ & 61 & $8640 \pm 3799^{*}$ & 42 & $6036 \pm 3372$ & 58 & $\begin{array}{r}6182(\mathrm{w}) \\
6809(\mathrm{~m}) \\
\infty\end{array}$ \\
\hline Total protein (g) & $47 \pm 31^{*}$ & 54 & $86 \pm 48^{*}$ & 27 & $55 \pm 38$ & 47 & 46 \\
\hline Plant protein (g) & $21 \pm 13^{*}$ & & $32 \pm 14^{*}$ & & $23 \pm 14$ & & \\
\hline $\begin{array}{l}\text { Animal protein } \\
(\mathrm{g})\end{array}$ & $26 \pm 27^{*}$ & & $54 \pm 41^{*}$ & & $32 \pm 32$ & & \\
\hline Total fat $(\mathrm{g})$ & $28 \pm 21^{*}$ & & $49 \pm 32^{*}$ & & $32 \pm 25$ & & \\
\hline Cholesterol (mg) & $124.6 \pm 151.5^{*}$ & & $260.7 \pm 217.2^{*}$ & & $151.5 \pm 174.1$ & & \\
\hline $\begin{array}{l}\text { Carbohydrates } \\
\text { (g) }\end{array}$ & $196.4 \pm 122.8^{*}$ & 19 & $300.9 \pm 138.5^{*}$ & 4 & $217 \pm 132$ & 15 & 100 \\
\hline $\begin{array}{l}\text { Total dietary } \\
\text { fibre }(\mathrm{g})\end{array}$ & $12 \pm 7^{* *}$ & 86 & $15 \pm 6^{* *}$ & 85 & $12 \pm 7$ & 85 & $21 \#$ \\
\hline Calcium (mg) & $214.6 \pm 209.8$ & 100 & $238.7 \pm 240.6$ & 100 & $219.3 \pm 215.2$ & 100 & 1200 \# \\
\hline Iron (mg) & $5.5 \pm 3.3^{* *}$ & 47 & $8.5 \pm 4.3^{* *}$ & 23 & $6.1 \pm 3.7$ & 41 & 5 \\
\hline Magnesium (mg) & $222.8 \pm 124.8^{\star *}$ & 61 & $318.2 \pm 127.1^{* *}$ & 35 & $241.7 \pm 130.4$ & 54 & 265 \\
\hline Zinc (mg) & $5.8 \pm 3.7^{* *}$ & 60 & $11.5 \pm 8.2^{* *}$ & 35 & $6.9 \pm 5.4$ & 53 & 6.8 \\
\hline Copper (mg) & $0.6 \pm 0.3^{* *}$ & & $0.9 \pm 0.4^{* *}$ & & $0.6 \pm 0.4$ & & \\
\hline Chromium $(\mu \mathrm{g})$ & $21.4 \pm 29.6^{* *}$ & 57 & $60.4 \pm 51.2^{* *}$ & 35 & $29.1 \pm 38.0$ & 51 & $20 \#$ \\
\hline Selenium $(\mu \mathrm{g})$ & $19.1 \pm 17.2^{*}$ & 86 & $42.2 \pm 27.5^{*}$ & 65 & $23.7 \pm 21.6$ & 81 & 45 \\
\hline $\begin{array}{l}\text { Vitamin A ( } \mu \mathrm{g} \\
\mathrm{RE})\end{array}$ & $361.1 \pm 765.7$ & 80 & $447.7 \pm 746.3$ & 77 & $378.3 \pm 759.0$ & 78 & 500 \\
\hline Thiamin (mg) & $0.8 \pm 0.5^{*}$ & 61 & $1.3 \pm 0.6^{*}$ & 35 & $0.9 \pm 0.6$ & 56 & 0.9 \\
\hline Riboflavin (mg) & $0.7 \pm 0.8$ & 79 & $0.9 \pm 0.6$ & 58 & $0.7 \pm 0.8$ & 64 & 0.9 \\
\hline Niacin (mg) & $9.8 \pm 6.8^{* *}$ & 59 & $16.8 \pm 9.0^{* *}$ & 23 & $11.1 \pm 7.8$ & 50 & 11 \\
\hline Vitamin B6 (mg) & $0.7 \pm 0.5$ & 87 & $1.2 \pm 0.9$ & 73 & $0.8 \pm 0.6$ & 78 & 1.3 \\
\hline Folate $(\mu \mathrm{g})$ & $136.3 \pm 124.9$ & 89 & $165.5 \pm 99.5$ & 92 & $142.0 \pm 120.4$ & 90 & 320 \\
\hline Vitamin B12 $(\mu \mathrm{g})$ & $1.9 \pm 3.1$ & 67 & $3.3 \pm 3.2$ & 50 & $2.2 \pm 3.1$ & 61 & 2 \\
\hline $\begin{array}{l}\text { Pantothenate } \\
(\mathrm{mg})\end{array}$ & $3.6 \pm 3.1^{* *}$ & 69 & $5.9 \pm 4.0^{* *}$ & 65 & $4.1 \pm 3.4$ & 68 & $5 \#$ \\
\hline Biotin $(\mu \mathrm{g})$ & $19.4 \pm 27.6$ & 84 & $25.9 \pm 12.0$ & 62 & $20.7 \pm 25.4$ & 79 & $30 \#$ \\
\hline Vitamin C (mg) & $32.4 \pm 69.7$ & 83 & $65.6 \pm 166.2$ & 85 & $39.0 \pm 96.5$ & 83 & 60 \\
\hline Vitamin D $(\mu g)$ & $1.2 \pm 2.1^{* *}$ & 100 & $3.3 \pm 3.9^{* *}$ & 100 & $1.6 \pm 2.7$ & 100 & $10 \#$ \\
\hline Vitamin E (mg) & $3.9 \pm 6.7$ & 99 & $6.3 \pm 5.9$ & 88 & $4.4 \pm 6.6$ & 98 & 12 \\
\hline \multicolumn{8}{|c|}{$\begin{array}{l}\text { *Statistically significant difference between men and women at } p \leq 0.01 \text { (Levene's test for equality of variances) } \\
\text { ** Statistically significant difference between men and women at } p \leq 0.05 \text { (Levene's test for equality of variances) } \\
\infty \text { Estimated Energy Requirements (Institute of Medicine, 2003) for sedentary men aged } 71.3 \text { years, height }=1.67 \mathrm{~m} \\
\text { and weight }=76.3 \mathrm{~kg} \text { and females of } 71.8 \text { years, height }=1.6 \mathrm{~m} \text { and } 75.8 \mathrm{~kg} \\
\text { T Estimated Average Requirement for females aged } 51-70 \text { years old } \\
\text { \# Adequate Intake levels for females aged } 51-70 \text { years old (Institute of Medicine, 2003) }\end{array}$} \\
\hline
\end{tabular}


Table 3: Top 20 food items consumed measured by 24-hour

\begin{tabular}{|l|r|r|}
\hline \multicolumn{1}{|c|}{ Food item } & $\begin{array}{c}\text { Mean daily intake } \\
\text { (gram per person } \\
\text { consuming these } \\
\text { foods) }\end{array}$ & $\begin{array}{c}\text { Number of } \\
\text { respondents with } \\
\text { daily consumption }\end{array}$ \\
\hline Tea, brewed & 299 & 119 \\
\hline Maize meal, cooked, stiff porridge & 273 & 79 \\
\hline Brown bread/rolls & 93 & 89 \\
\hline Milk, full cream, fresh & 67 & 73 \\
\hline Chicken & 103 & 38 \\
\hline Beef & 125 & 21 \\
\hline Fermented maize drink (mageu) & 212 & 15 \\
\hline Egg, cooked & 123 & 24 \\
\hline Apple & 160 & 15 \\
\hline Orange & 189 & 11 \\
\hline Maltabella, cooked (sorghum) & 281 & 6 \\
\hline Coffee, brewed, instant & 267 & 6 \\
\hline Potato, boiled & 105 & 15 \\
\hline Sugar, white & 16 & 95 \\
\hline Cold drink, carbonated & 280 & 5 \\
\hline Soup, bean and meat & 321 & 4 \\
\hline Orange Juice & 319 & 4 \\
\hline Rice, white, cooked & 87 & 14 \\
\hline Cabbage, cooked & 46 & 22 \\
\hline Spinach, cooked & 49 & 18 \\
\hline
\end{tabular}

\section{Income levels and procurement patterns}

All the respondents in the sample received a state pension and the majority had been receiving this for longer than three years. In $4.2 \%$ of the cases the partner was employed. The majority of households had a monthly income of between R501 and R1 000 and in most of the households the pensioner was the only contributor to household income. The majority of respondents spent less than R200 per week on food for the household. The results further indicated that in these households the mother (31.2\%) or grandmother $(54.7 \%)$ was responsible for household expenditure. In a relatively large percentage of households the grandmother was responsible for food preparation (40.6\%), food procurement decisions (47\%), and feeding the children (43.5\%), and was regarded as the head of the family $(54.7 \%)$. In the South African context, it is known that many grandparents have become "silent saviours" of grandchildren whose parents cannot look after them for a variety of reasons, including HIVIAIDS. At least one in five AIDS-affected households is headed by a woman older than 60 years (Steinberg, Johnson \& Ndegwa, 2002:12).
The results in Table 4 indicate household food insecurity based on the fact that $7.4 \%$ of the respondents reported a chronic money shortage to procure their basic needs, whilst $47.9 \%$ often had this problem and $25.1 \%$ sometimes did not have enough money for their basic needs. Only a small percentage seldom or never experienced this problem.

\section{DISCUSSION}

The purpose of this study was to determine the demographic and health profile and nutritional status of elderly people attending a care centre in Sharpeville, in order to develop appropriate nutrition intervention programmes to meet their needs and tastes for maximum compliance. A limitation of this study was the small sample of men $(n=16)$ and the results for the men therefore cannot be generalised. Another limitation is that dietary intake was measured on the days that the elderly did not consume a meal at the elderly care centre. The dietary intake results may have been different on days that the elderly attended the care centre.

Sharpeville has a population of 45000 people (Mcllrath \& Slabbert, 2003:45) and thus an estimated 
Table 4: Food procurement and preparation patterns of the sample $(n=169)$

\begin{tabular}{|c|c|c|}
\hline Variable & $\mathrm{N}$ & $\%$ \\
\hline Frequency of food shopping & 170 & 100 \\
\hline Every day & 8 & 4.7 \\
\hline Once a week & 12 & 7 \\
\hline Once a month & 139 & 81.8 \\
\hline When money available & 11 & 6.5 \\
\hline Place where food is bought most of the time & 170 & 100 \\
\hline Spaza shop & 9 & 5.3 \\
\hline Street vendor & 4 & 2.4 \\
\hline Supermarket & 116 & 68.2 \\
\hline Spaza shop \& street vendor & 3 & 1.8 \\
\hline Spaza shop \& supermarket & 7 & 4.1 \\
\hline Street vendor \& supermarket & 18 & 10.6 \\
\hline Market & 13 & 7.6 \\
\hline Weekly food expenditure & 160 & 100 \\
\hline R0 -R50 (0-8 US\$) & 30 & 18.8 \\
\hline R51-R100 (9-15 US\$) & 34 & 21.2 \\
\hline R101-R 150 (16-23 US\$) & 18 & 11.2 \\
\hline R151-R200 (24-30 US\$ & 19 & 11.9 \\
\hline$>$ R 200 (30 US\$) & 32 & 20 \\
\hline Do not know & 27 & 16.9 \\
\hline $\begin{array}{l}\text { Household member responsible for food } \\
\text { preparation }\end{array}$ & 170 & 100 \\
\hline Mother & 74 & 43.5 \\
\hline Grandmother & 69 & 40.6 \\
\hline Other (mother, father, caregiver, child) & 27 & 15.9 \\
\hline $\begin{array}{l}\text { Household member responsible for food } \\
\text { procurement decisions }\end{array}$ & 170 & 100 \\
\hline Mother & 44 & 25.9 \\
\hline Grandmother & 80 & 47 \\
\hline Other (mother, father, caregiver, child) & 46 & 27.1 \\
\hline $\begin{array}{l}\text { Household member responsible for feeding the } \\
\text { children }\end{array}$ & 170 & 100 \\
\hline Mother & 63 & 37.1 \\
\hline Grandmother & 74 & 43.5 \\
\hline Other (mother, father, caregiver, child) & 33 & 19.4 \\
\hline Reported head of the household & 170 & 100 \\
\hline Mother & 53 & 31.2 \\
\hline Grandmother & 93 & 54.7 \\
\hline $\begin{array}{l}\text { Other (mother, father, caregiver in absence of } \\
\text { family) }\end{array}$ & 24 & 14.1 \\
\hline Number of meals served per household per day & 170 & 100 \\
\hline 1 & 10 & 5.9 \\
\hline 2 & 49 & 28.8 \\
\hline 3 & 100 & 58.8 \\
\hline$>3$ & 11 & 6.5 \\
\hline Place where most of the food is consumed & 170 & 100 \\
\hline Home & 170 & 100 \\
\hline $\begin{array}{l}\text { Frequency of money shortage for basic needs } \\
\text { in household }\end{array}$ & 163 & 100 \\
\hline Always & 12 & 7.4 \\
\hline Often & 78 & 47.9 \\
\hline Sometimes & 41 & 25.1 \\
\hline Seldom & 17 & 10.4 \\
\hline Never & 15 & 9.2 \\
\hline
\end{tabular}


3285 elderly (based on the fact that $7.3 \%$ of the South African population is elderly (Joubert \& Bradshaw, 2006:204)). Furthermore, not all the elderly in Sharpeville attend care centres and the results of this study therefore cannot be generalised, as this sample of elderly people is not representative of all the elderly living in Sharpeville or the rest of SA.

Obesity was the most outstanding anthropometric feature of the women in this study, exceeding the prevalence reported for black women in the Cape Peninsula (Charlton et al., 2005:1038; Steyn, Jooste, Bourne, Fourie, Badenhorst, Bourne, Langenhoven, Lombard, Truter \& Katzenellenbogen, 1991:483) and in the South African Demographic and Health Survey conducted in 1998 (Puoane, Steyn, Bradshaw, Laubscher, Fourie, Lambert \& Mbananga, 2002:1044). A high rate of obesity in black South African women has also been reported by researchers in other provinces (Mollentze, Moore, Steyn, Joubert, Steyn, Oosthuizen \& Weich, 1995:93; Kruger, Venter \& Vorster, 2001:735). About two decades ago, Walker, Walker, Walker and Vorster (1989:226) referred to obesity in these women as "healthy obesity" because adverse sequelae of obesity were found in only $12.5 \%$ of obese women and $87.5 \%$ were free of any sign of the metabolic syndrome. However, more recently obesity in African women has been associated with an increased risk of noncommunicable diseases (NCDs) (Mollentze et al., 1995:92-94; Kruger et al., 2001:735-737) as was found in the study reported here. There is a growing perception that, in developing countries throughout the world, overnutrition-related chronic diseases such as obesity, diabetes mellitus, CVD and certain forms of cancer often develop before the battle against undernutrition has been won. In SA, the coexistence of undernutrition with overnutrition is evident from the already high prevalence of micronutrient deficiencies accompanied by the very high prevalence of obesity in black women, as well as hypertension and stroke in urban Africans (OldewageTheron, 2001:160). It is known that hunger and obesity can exist within the same household (Townsend, 2006:34; Scheier, 2005:883). This is especially true for low-income households, as was found in this community. There is evidence that higher obesity rates tend to be associated with low incomes and low education levels, particularly among women (Wardle, 2002:1230). One explanation for this arises from the effect of prices and incomes on food choices, dietary habits and diet quality. Drewnowski and Specter (2004:11) hypothesised that consuming energy-dense foods and energy-dense diets are an important strategy used by low-income consumers to stretch the food budget. Energy-dense foods carry a lower price tag, which allows for higher energy consumption. They concluded that limited economic resources may shift dietary choices towards an energy-dense, highly palatable diet, as this kind of diet provides maximum calories per the least volume and the least cost. But with the observed mean energy intake in this study, which was actually low in comparison to the EER (Institute of Medicine, 2003), the 'food acquisition cycle' proposed by Townsend, Peerson, Love, Achterberg and Murphy (2001:1741) may explain our observations more appropriately. Food insecure families overeat when food is plentiful (when money for food is available), followed by a short period of involuntary food restriction (when money is in short supply), followed by overeating. This could be a pattern that results in gradual weight gain over time. According to Olsen (1999:S523), the relationship between food insecurity and obesity is a "complicated and politically charged topic". The chronic ups and downs in the economic cycle of households that show fiscal constraint cause these people to eat more when food is available (Polivy, 1996:590).

The socio-economic status of the participants in this study was poor. Although all the elderly persons who participated in the study received a monthly pension, they were the only contributors to household income in most of the households and the majority of households had a monthly income of between R501 and R1 000. More than $80 \%$ of the respondents reported an occasional shortage of funds for basic household needs, which confirmed the presence of food insecurity. Most of the households spent less than R200 per week on food. Taking into consideration that the average household size was 4.9 people, spending on food was calculated to be less than $\mathrm{R} 5,80$ per person per day. This is equivalent to a loaf of bread or a litre of milk. This was also evident from the type of foods consumed. The top 20 food consumption list indicates that the majority of food items consumed were carbohydratebased with a low frequency of small portions of fruit and vegetables, not meeting the recommended intake of $400 \mathrm{~g}$ per day (Love \& Sayed, 2001:S29). This is in agreement with the THUSA (Transition in Health during Urbanisation in South Africa) study, in which regular 
fruit and vegetable consumption was found only in the upper class urban stratum (MacIntyre, Kruger, Venter \& Vorster, 2002:250).

Although the mean daily protein intake was sufficient, about half of the protein intake of the women was derived from plant sources. Furthermore, the intakes of the women were deficient for total energy and dietary fibre, as well as a large number of micronutrients. These results correspond with similar studies conducted amongst black elderly persons in South Africa (Charlton et al., 2005:2034) and in the THUSA study (Maclntyre et al., 2002:244-246). However, the very low zinc status (dietary intake as well as serum values) was an unexpected finding. Zinc has been one of the micronutrients in enriched maize meal in SA by law since April 2003 in amounts of 1.89 to $2.66 \mathrm{mg}$ per 100 $\mathrm{g}$ raw maize meal, depending upon the degree of refinement. For stiff maize porridge, this amounts to about $1.9 \mathrm{mg}$ per $100 \mathrm{~g}$ (Department of Health, 2003:5). The mean intake of maize porridge in the study was $273 \mathrm{~g}$, supplying about $5.2 \mathrm{mg}$ zinc, compared to the RDA of 8 and $11 \mathrm{mg}$ for women and men, respectively. However, very few other dietary sources of zinc were included in the diets of the respondents. Thus the predominant food source of zinc for these elderly was maize meal. However, the bioavailability of zinc is better from animal sources than plant sources. Furthermore, the presence of phytate in diets can reduce zinc absorption. Poor bioavailability of zinc has been reported among populations consuming a predominantly maizebased diet and this is a hindrance to achieving adequate zinc nutriture (Gibson, 2005:712). Cereals contain a high content of the anti-nutritional factor phytate (Gibson, Perlas \& Hotz 2006:160; Manary, Hotz, Krebs, Gibson,Westcott,Broadhead \& Hambidge, 2002:1057), which reduces the bioavailability of zinc. Samples of maize meal from six provinces in South Africa were recently analysed for their phytate content at the NorthWest University, Potchefstroom, and verified by an agricultural research laboratory. The phytate content ranged from 1 237-1 $631 \mathrm{mg} / 100 \mathrm{~g}$ maize meal, (Pisa, 2006:32), which is substantially higher than the content reported by Ferguson, Gibson, Thompson, Ounpuu and Berry (1988:320) for East African maize meal $(792$ mg/ $100 \mathrm{~g}$ ). The inhibitory effect of phytate on zinc absorption is due to it forming insoluble complexes with zinc in the gastrointestinal tract (Gibson, 2005:714; Manary et al., 2002:1057). Manary and co-authors (2002:1057) found an inhibitory effect of habitual high dietary phytate intake on zinc homeostasis in Malawian children. Furthermore, the molar ratio phytate:zinc can be used as a determinant of zinc bioavailability from cereal-based meals. The mean phytate:zinc molar ratio of maize samples from the Vaal region was 44 (Pisa, 2006:33), which fell well above the ratio for optimal relative bioavailability of 15 (Navert, Sandstrom \& Cederblad, 1985:52). In view of these considerations, reduced bioavailability may, therefore, partly explain why low serum zinc values were common.

The health status of the respondents was also compromised. Although smoking and alcohol consumption were relatively low, environmentally this area suffers high pollution rates as it is an industrial area. A large number of elderly persons were taking chronic medication and suffered from a number of disorders including painful joints, ear, nose and throat infections and chronic headaches. Although $40.6 \%$ of the respondents received chronic blood pressure medication, only $10 \%$ had a normal blood pressure. The high prevalence of hypertension in this study corresponds with the THUSA population (Van Rooyen et al., 2000:783). A study conducted in KwaZulu-Natal also found the black population had a high prevalence of hypertension (25\%), higher than in any of the other population groups in SA (Seedat \& Seedat, 1982:62). Recently, Vorster (2002:239) reviewed the emergence of CVD in urbanisation of Africans. It appeared that mortality rates from CVD confirmed that stroke is a major public health problem amongst black South Africans, possibly because of an increase in hypertension, obesity, smoking and hyperfibrinogenaemia in urbanisation. Available data further suggested that black South Africans might be protected against ischaemic heart disease (IHD) because of favourable serum lipid profiles (low total cholesterol and high ratios of highdensity lipoprotein cholesterol) and low homocysteine values (Vorster, 2002:242). However, in the study reported here, almost half of the women and a third of the men had total serum cholesterol values above defined cut-off points, increasing the IHD risk profile. This adds urgency to the efforts suggested by Mollentze et al. (1995:95) to take measures to prevent an epidemic of atherosclerotic vascular disease in the black population. Communities with a low socio-economic status, such as in this study, are particularly vulnerable given the relationship between CVD and socio-economic sta- 
tus reported in the literature (Strike \& Steptoe, 2004:338).

Older adults are known to be at an increased risk for impaired nutritional status with increasing age. However, in SA, the elderly are not considered a priority when planning nutrition interventions and as a result, the impact and effectiveness of such studies have not been described for this population (Charlton \& Rose, 2001:2424S). Poor dietary intake, especially of zinc, as shown to be a problem in this particular community, may result in impaired immunity which will lead to an increased risk of infectious disease (Cowan, Roberts, Fitzpatrick, While \& Baldwin, 2004:229; Bernstein, Tucker, Ryan, O’Neill, Clements, Nelson, Evans \& Fiatarone Singh, 2002:1096-7). While these adverse effects are applicable to all age groups, the elderly group is especially at risk and the many side effects of malnutrition may exacerbate one another, particularly in frail elderly people (Cowan et al., 2004:229). However, in a climate where HIVIAIDS is the major public health problem consuming the largest portion of the health budget, and policies promoting the wellbeing of the elderly are not considered a priority, affordable, effective and culturally sensitive programmes remain a major challenge.

\section{CONCLUSION}

The findings of this study confirm that poverty, malnutrition, both undernutrition and overnutrition, as well as household food insecurity and poor health were the major problems observed in this elderly community. These findings correspond to other studies, however limited, conducted amongst the elderly in SA (Charlton, 2000:S33) and confirm the need to educate the older adults in this community to enable them to modify their food procurement patterns as well as their dietary practices to address the high prevalence of obesity and associated risk of hypertension and diabetes mellitus. Economics remains a critical issue as it will influence which foods are bought and also where people can afford to live and thus their proximity to food stores and outlets, as well as to public health services. Counselling on food procurement and preparation skills should thus accompany nutrition education (Sayhoun, Pratt \&Anderson, 2004:67). Researchers have demonstrated that nutrition education for the elderly is necessary, as well as possible, to prevent or delay the spiral towards ill health and thus disability (Sayhoun et al., 2004:67). Obesity prevention or remediation may be especially challenging in black elderly people because of the positive traditional and cultural connotations ascribed to obesity (Mvo, Dick \& Steyn, 1999:27). In a traditional African context, an obese figure is often regarded as a sign of affluence and happiness. With the prevalence of HIVIAIDS that is increasing in the current South African situation, obesity even seems to be observed as an indication of a person's health as weight loss is often associated with HIVIAIDS (Mvo et al., 1999:30).

The results of this study will form the basis for planning and implementing sustainable nutrition intervention and education programmes, to promote public health amongst this group of elderly in the Vaal Region. An intervention study addressing the prevalent zinc deficiency in this elderly community is also needed. Zinc is important for immunity (Haase, Mocchegiani \& Rink, 2006:426; Sandstead, Henriksen, Greger, Prasad \& Good, 1982:1054) and should this be addressed, this could also lead to a healthier community (Prasad, Beck, Bao, Fitzgerald, Snell, Steinberg \& Cardozo, 2007:840). A short-term multi-micronutrient supplementation programme should be implemented to build up the depleted zinc and iron stores, followed by a long-term food-based intervention to maintain the serum zinc and iron levels. A cost-effective way of increasing the zinc intake would be to include more legumes in the diet as these prove to be good sources of zinc and iron. The zinc content of $100 \mathrm{~g}$ cooked sugar beans is $1.06 \mathrm{mg}$ compared to $1.53 \mathrm{mg}, 1.27 \mathrm{mg}, 1.0 \mathrm{mg}$ and $1.15 \mathrm{mg}$ of $100 \mathrm{~g}$ of cooked chickpeas, lentils, split peas and soybeans, respectively. The iron content for the same food items is $2.1 \mathrm{mg}, 2.9 \mathrm{mg}, 3.3 \mathrm{mg}, 1.3 \mathrm{mg}$ and 5.1 mg, respectively (Langenhoven, Kruger, Gouws \& Faber, 1991:149). Improving the nutritional status of the elderly through nutrition interventions may result in physical and cognitive functional ability (Gray, Hanlon, Landerman, Artz, Schmader \& Fillenbaum, 2003:3, 6; Huskisson, Maggini \& Ruf, 2007:1; Marcellini, Giuli, Papa, Gagliardi, Dedoussis, Herbein, Fulop, Monti, Rink, Jatje \& Mocchegiani, 2006:339), as well as cost savings related to medical care and utilisation of limited health care resources in SA (Charlton \& Rose, 2001:2427S). 


\section{ACKNOWLEDGEMENTS}

We hereby acknowledge the Department of Health in the Vaal Triangle for their cooperation, the Vaal University of Technology and National Research Foundation for funding this project, as well as the management and participants of the Elderly Care Centre in Sharpeville. We want to furthermore acknowledge Tom Ndanu (bio-statistician), Verena Nolan (statistician) and Lizelle Oosthuizen (dietician and research assistant) for their valuable assistance.

\section{REFERENCES}

BERNSTEIN, MA; TUCKER, KL; RYAN, ND; O'NEILL, EF; CLEMENTS, KM; NELSON, ME; EVANS, WJ \& FIATARONE SINGH, MAF 2002: Higher dietary variety is associated with better nutritional status in frail elderly people. Journal of the American Dietetic Association, 102(8):1096:1104.

CANNON, G 2001: Diet-related chronic diseases. Focus, 5 (brief 8 of 11), Feb:1-2.

CHARLTON, KE 2000: Nutrition, health and old age - The case of South African urban elderly. South African Journal of Clinical Nutrition, 13(1):S31-S35.

CHARLTON, KE; BOURNE, LT; STEYN, K \& LAUBSCHER, JA2001: Poor nutritional status in older black South Africans. Asia Pacific Journal of Clinical Nutrition, 10(1):31-38.

CHARLTON, KE; KOLBE-ALEXANDER, TL \& NEL, JH 2005: Micronutrient dilution associated with added sugar intake in elderly black South African women. European Journal of Clinical Nutrition, 59(9):1030-1042.

CHARLTON, KE \& ROSE, D 2001: Nutrition among older adults in Africa: the situation at the beginning of the millennium. Journal of Nutrition, 131(9), Sept:2424S-2428S.

COWAN, DT; ROBERTS, JD; FITZPATRICK, JM; WHILE, AE \& BALDWIN, J 2004: Nutritional status of older people in long term care settings: Current status and future directions. International Journal of Nursing Studies, 41:225-237.

DAUSCH, JG 2003: Aging issues moving mainstream. Journal of the American Dietetic Association, 103(6):683-684.

DEPARTMENT OF HEALTH 2003: Regulations relating to the fortification of certainfoodstuffs.

Www.file:/E:IThe \%Department $\% 20$ of $\% 20$ Health $\% 20$ \%20Search_fileslffortification.htm (Accessed on 06 June 2006). DREWNOWSKI, A\& SPECTER, SE 2004: Poverty and obesity: The role of energy density and energy costs. American Journal of Clinical Nutrition, 79(1):6-16.

FERGUSON, EL; GIBSON, RS; THOMPSON, LU; OUNPUU, S \& BERRY, M 1988: Phytate, zinc and calcium contents of 30 East
African foods and their calculated phytate: $\mathrm{Zn}, \mathrm{Ca}$ : phytate, and [Ca][phytate]/[Zn] molar ratios. Journal of Food Composition and Analysis, 1(4):316-325.

GIBSON, RS. 2005. Principles of nutritional assessment; $2^{\text {nd }}$ edition. New York: Oxford University Press.

GIBSON, RS; PERLAS, L \& HOTZ, C 2006. Improving the bioavailability of nutrients in plant foods at the household level. Proceedings of the Nutrition Society, 65(2):160-168. GRAY, SL; HANLON, JT; LANDERMAN, LR; ARTZ, M; SCHMADER, KE \& FILLENBAUM, GG 2003: Is antioxidant use protective of cognitive function in the community-dwelling elderly? The American Journal of Geriatric Pharmacotherapy, 1(1):310.

HAASE, H; MOCCHEGIANI, E \& RINK, L 2006: Correlation between zinc status and immune function in the elderly. Biogerontology, 7(5-6):421-428.

HUSKISSON, E; MAGGINI, S \& RUF, M 2007: The influence of micronutrients on cognitive function and performance. Journal of International Medical Research, 35(1):1-19.

INSTITUTE OF MEDICINE 2003: Dietary reference intakes. Food and Nutrition Board. Washington DC: National Academy Press. JOUBERT, J \& BRADSHAW, D 2006: Population ageing and health challenges in South Africa. (In: Steyn, K; Fourie, J \& Temple, N eds. 2005: Chronic diseases of lifestyle in South Africa 19952005: Cape Town: Medical Research Council, pp 204-219).

KRUGER, HS; VENTER, CS \& VORSTER, HH 2001: Obesity in African women in the North West Province, South Africa is associated with an increased risk of non-communicable diseases: The THUSA study. British Journal of Nutrition, 86(6):733-740. LANGENHOVEN, M; KRUGER, M; GOUWS, E \& FABER, M 1991: MRC food composition tables; $3^{\text {rd }}$ edition. Cape Town: MRC.

LEMKE, S; JANSEN VAN RENSBURG, F; VORSTER, H \& ZICHEA, J 2001: Black South African families, intra-household relations and food and nutrition security - Creativity for survival. Annals of Nutrition and Metabolism, 45(S1), Aug:21.

LOVE, P \& SAYED, N 2001: Eat plenty of vegetables and fruits every day. South African Journal of Clinical Nutrition, 14(3):S24-S32.

MACINTYRE, UE; KRUGER, HS; VENTER, CS \& VORSTER, HH 2002: Dietary intakes of an African population in different stages of transition in the North West Province, South Africa: The THUSA study. Nutrition Research, 22:239-256.

MAHAN, LK \& ESCOTT-STUMP, S 2000: Krause's food, nutrition and diet therapy. Philadelphia: WB Saunders Company. MANARY, MJ; HOTZ, C; KREBS, NF; GIBSON, RS; WESTCOTT, JE; BROADHEAD, RL \& HAMBIDGE, KM 2002: Zinc homeostasis in Malawian children consuming a high-phytate, maize-based diet. American Journal of Clinical Nutrition, 75(6):1056-1061. MARCELINNI, F; GIULI, C; PAPA, R; GAGLIARDI, C; DEDOUSSIS, G; 
HERBEIN, G; FULOP, T; MONTI, D; RINK, L; JATJE, J \& MOCCHEGIANI, E 2006: Zinc status, psychological and nutritional assessment in old people recruited in five European countries: Zincage study. Biogerontology, 7(5-6):339-445.

MARGETTS, BM \& NELSON, M 2000: Design concepts in nutritional epidemiology; $2^{\text {nd }}$ edition. New York: Oxford University Press. MCILRATH, L \& SLABBERT, T 2003: Sedibeng Economic Regeneration Summit. Vanderbijlpark: Sedibeng Municipality. MOLLENTZE, WF; MOORE, AJ; STEYN, AF; JOUBERT, G; STEYN, K; OOSTHUIZEN, GM \& WEICH, DJV 1995: Coronary heart disease in a rural and urban Orange Free State black population. South African Medical Journal, 85(2):90-96.

MVO, Z; DICK, J \& STEYN, K 1999: Perceptions of overweight African women about acceptable body size of women and children. Curationis, 22(2):27-31.

NAVERT, B; SANDSTROM, B \& CEDERBLAD, A 1985: Reduction of the phytate content of bran by leavening in bread and its effect on zinc absorption in man. British Journal of Nutrition, 53:47-53. OLDEWAGE-THERON, WH 2001: Evaluation of the fortification of sugar with vitamin. Potchefstroom: University for CHE (Unpublished PhD thesis).

OLDEWAGE-THERON, WH; DICKS, EG; NAPIER, CE \& RUTENGWE, $R$ 2005: Situation analysis of an informal settlement in the Vaal Triangle. Development Southern Africa, 22(1):13-26.

OLSEN, CM 1999: Nutrition and health outcomes associated with food insecurity and hunger. Journal of Nutrition, 129(suppl 2):S521-S524.

PISA, P 2006: Determination of phytate, iron, calcium, zinc and the phytate to mineral molar ratios in maize meal from six South African provinces. Potchefstroom: North-West University (Unpublished BSc dissertation).

POLIVY, J 1996: Psychological consequences of food restriction. Journal of the American Dietetic Association, 96(6):589592.

PRASAD, AS; BECK, FWJ; BAO, B; FITZGERALD, JT; SNELL, DC; STEINBERG, JD \& CARDOZO, LJ 2007: Zinc supplementation decreases incidence of infections in the elderly: Effect of zinc on generation of cytokines and oxidative stress. American Journal of Clinical Nutrition, 85(3):837-844.

PUOANE, T; STEYN, K; BRADSHAW, D; LAUBSCHER, R; FOURIE, J; LAMBERT, V \& MBANANGA, N 2002: Obesity in South Africa: The South African Demographic and Health Survey. Obesity Research, 10(10):1038-1048.

SANDSTROM, B \& LONNERDAL, B 1989: Promoters and antagonists of zinc absorption. (In: Mills, CF ed. 1989: Zinc and human biology. London: Springer-Verlag, pp 57-78).

SANDSTEAD, HH; HENRIKSEN, LK; GREGER, JL; PRASAD, AS \& GOOD, RA 1982: Zinc nutriture in the elderly in relation to taste acuity, immune response, and wound healing. The American
Journal of Clinical Nutrition, 36(5):1046-1059.

SAYHOUN, NR; PRATT, CA \& ANDERSON, A 2004: Evaluation of nutrition education interventions for older adults: A proposed framework. Journal of the American Dietetic Association, 104(1):58-69.

SCHEIER, LM 2005: What is the hunger-obesity paradox? Journal of the American Dietetic Association, 105(6):883-886.

SEEDAT, YK \& SEEDAT, MA 1982: An inter-racial study of the prevalence of hypertension in an urban South African population. Transactions of the Royal Society for Tropical Medicine and Hygiene, 76(1):62-71.

SOLOMONS, NW 2001: Health and aging. Focus, 5 (brief 9 of 11), Feb:1-2.

STEINBERG, M; JOHNSON, S \& NDEGWA, D 2002: Hitting home: How households cope with the impact of the HIVIAIDS epidemic. Cape Town: Henry J Kaiser Foundation \& Health Systems Trust. STEYN, NP; BRADSHAW, D; NORMAN, R; JOUBERT, J; SCHNEIDER, M \& STEYN, K 2006: Dietary changes and the health transition in South Africa: Implications for health policy. Cape Town: Chronic Diseases of Lifestyle Unit and Burden of Disease Research Unit of the Medical Research Council.

STEYN, K; JOOSTE, PL; BOURNE, LT; FOURIE, J; BADENHORST, CJ; BOURNE, DE; LANGENHOVEN, ML; LOMBARD, CJ; TRUTER, H \& KATZENELLENBOGEN, J 1991: Risk factors for coronary heart disease in the black population of the Cape Peninsula. The BRISK study. South African Medical Journal, 79(8):480-485.

STRIKE, PC \& STEPTOE, A 2004: Psychosocial factors in the development of coronary artery disease. Progress in Cardiovascular Diseases, 46(4):337-347.

THE SURVEY SYSTEM n.d. Sample size calculator. http:// www.surveysystem.com/ssformu.htm (Accessed on 5 April 2004).

TOWNSEND, M 2006: Obesity in low-income communities: Prevalence, effects, a place to begin. Journal of the American Dietetic Association, 106(1):34-36.

TOWNSEND, M; PEERSON, J; LOVE, B; ACHTERBERG, C \& MURPHY, SP 2001: Food insecurity is positively related to overweight in women. Journal of Nutrition, 131(6):1738-1745. VAN ROOYEN, JM; KRUGER, HS; HUISMAN, HW; WISSING, MP; MARGETTS, B; VENTER, CS \& VORSTER, HH 2000: An epidemiological study of hypertension and its determinants in a population in transition: The THUSA study. Journal of Human Hypertension, 14(12), Dec:779-787.

VORSTER, HH 2002: The emergence of cardiovascular disease during urbanization of Africans. Public Health Nutrition, 5(1A):239-243.

WALKER, ARP; WALKER, BF; WALKER, AJ \& VORSTER, HH 1989: Low frequency of adverse sequelae of obesity in South African rural black women. International Journal of Vitamin Research, 
59(2):224-228.

WARDLE, J 2002: Sex differences in association with SES and obesity. American Journal of Public Health, 92(8):1299-1304. WELLMAN, N; WEDDLE, D; SANCHEZ, NK \& ROSENZWEIG, L2004: Eat better \& move more: A guide book for community programmes. Miami: National Resource Center on Nutrition, Physical Activity \& Aging.

WORLD HEALTH ORGANIZATION 1978: Expert Committee. Arterial hypertension. Technical Report Series no 628. Geneva.

YETISER, S; TOSUN, F; SATAR B; ARSLANHAN, M; AKCAM, T \& OZKAPTAN, Y 2002: The role of zinc in the management of tinnitus. Auris Nasus Larynx, 29(4):329-333. 